\title{
Evaluation of Hebei Province's Innovation Ability under the Integration of Beijing-Tianjin-Hebei
}

\author{
He Menghuan ${ }^{1, *}$ \\ ${ }^{1}$ School of Economics and Management, Beijing Jiaotong University, Haidian, Beijing, China
}

\begin{abstract}
Regional innovation capability is one of the important indicators to measure the comprehensive development level of a region. This paper uses the analytic hierarchy process to evaluate the regional innovation capability of Beijing-Tianjin-Hebei. A total of 10 indicators were selected from the three aspects of regional innovation foundation, regional innovation input and regional innovation output to construct a regional innovation capability evaluation index system. Using 2019 data to comprehensively evaluate the innovation capability of the Beijing-Tianjin-Hebei region. Finally, the regional innovation ability scores and basic rankings of Beijing, Tianjin, and Hebei provinces were obtained. The study concluded that Hebei Province still has many gaps in innovation input and innovation output compared with Beijing and Tianjin. Therefore, Hebei Province needs to strengthen its innovation input and innovation output. The integration of Beijing-Tianjin-Hebei has created good development opportunities for Hebei Province. Therefore, an objective evaluation of the scientific and technological innovation capabilities of Hebei Province under the integration of Beijing-Tianjin-Hebei is of certain significance for the government to formulate science and technology strategies and improve technological innovation capabilities.
\end{abstract}

\section{Introduction}

The Beijing-Tianjin-Hebei region is located in North China and includes 13 cities including Beijing, Tianjin and Shijiazhuang. In 2018, the Central Committee of the Communist Party of China clearly stated in the "Opinions on Establishing a More Effective New Mechanism for Regional Coordinated Development" that Beijing and Tianjin will be the center to lead the development of the Beijing-Tianjin-Hebei urban agglomeration. In this context, the evaluation research on the innovation capability of the Beijing-Tianjin-Hebei region is of great significance. In the context of the Beijing-Tianjin-Hebei integration strategy, Hebei Province has increased its core driving role in scientific and technological innovation, and in 2020 will achieve "three improvements, two breakthroughs, and one guarantee". In order to explain the scientific and technological innovation ability of Hebei Province more clearly, this paper adopts a quantitative and weighted method to evaluate the scientific and technological innovation ability of Hebei Province under the integration of Beijing-Tianjin-Hebei, and uses a comparative research method to compare with Beijing and Tianjin. In this way, it provides reference opinions for the future development of scientific and technological innovation in Hebei.

\section{Research Status}

Regional innovation capability indicates the transformation capability of innovation activities within a certain space, and the evaluation of regional innovation capability can explain the level of regional innovation. At present, the most common evaluation methods for evaluating regional innovation ability mainly include analytic hierarchy process (AHP), factor analysis, data envelopment analysis (DEA), ideal solution (TOPSIS), etc.

Li Baizhou (2010) used AHP to evaluate the original innovation capabilities of large enterprises and summarized the main factors affecting the original innovation capabilities of large enterprises ${ }^{[1]}$; Xiao Yonghong et al. (2012) used AHP and a coefficient of variation weighting method to evaluate the innovation of 54 national high-tech zones in my country ability ${ }^{[2]}$; Yang Guimei et al. (2017) used AHP to evaluate the innovation ability of agricultural science and technology in Anhui Province ${ }^{[3]}$; Xia Yanlei (2017) used AHP to evaluate the innovation ability of 6 agricultural science and technology parks in Anhui Province ${ }^{[4]}$; Wang Tao et al. (2010) used factor analysis to evaluate the technology of national high-tech zones Innovation ability ${ }^{[5]}$; Zhang Yixuan (2017) used DEA to evaluate the development of technological innovation in Hefei ${ }^{[6]}$; Chen Xin (2009) used TOPSIS method to evaluate the independent innovation ability of regional enterprises. ${ }^{[7]}$

To study Hebei Province's innovation capability 
improvement strategy, we need to objectively and systematically understand the development characteristics of Hebei Province's innovation capability. In recent years, domestic scholars have carried out a series of studies on Hebei Province's innovation capabilities. Yu Hualong et al. (2008) established the evaluation system of scientific and technological innovation capabilities of universities and conducted empirical research on the scientific and technological innovation capabilities of universities in Hebei Province ${ }^{[8]}$; Song Zhijie et al.(2008) Research on the improvement of regional innovation capacity in Hebei Province, and get the factors affecting regional innovation capacity ${ }^{[9]}$; Pang Xiuping et al. (2013) constructed a fuzzy comprehensive evaluation model and conducted an empirical study on the fuzzy comprehensive evaluation of Hebei Province's scientific and technological innovation capabilities. ${ }^{[10]}$

\section{Research design}

\subsection{Construction of evaluation index system of regional innovation ability in Beijing-Tianjin- Hebei region}

According to the literature research of regional innovation ability evaluation, combined with the actual situation of my country's Beijing-Tianjin-Hebei regional innovation activities. At the same time, taking into account the availability of data, the scientific nature of evaluation and the operability, the indicator system of regional innovation capability evaluation is mainly constructed from three aspects: regional innovation foundation, regional innovation input, and regional innovation output. As shown in Figure 1, the constructed hierarchical analysis structure includes the target layer (A), the criterion layer (B1, B2, B3), and the indicator layer (C1C10).

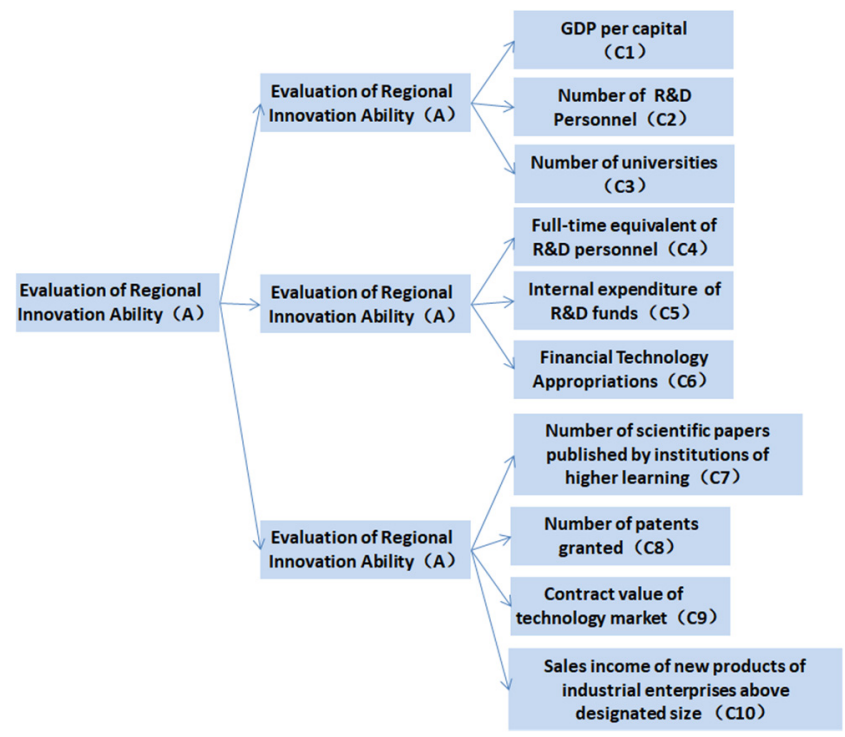

Fig 1. Evaluation Index System of Regional Innovation Ability in Beijing-Tianjin-Hebei Region.

\subsection{Determination of indicator weight}

As shown in Table 1, the expert scoring method is used to determine the weight of each indicator, and the expert scoring result is input into the yaahp software to obtain the indicator weight.

Table1. The weight of regional innovation ability evaluation index.

\begin{tabular}{|c|c|c|c|c|}
\hline $\begin{array}{c}\text { Evaluation } \\
\text { index }\end{array}$ & \multicolumn{3}{|c|}{ Evaluation weight } & $\begin{array}{c}\text { Index layer } \\
\text { combination } \\
\text { weight }\end{array}$ \\
\hline $\mathrm{C} 1$ & 0.6333 & 0 & 0 & 0.1791 \\
\hline $\mathrm{C} 2$ & 0.2605 & 0 & 0 & 0.0737 \\
\hline $\mathrm{C} 3$ & 0.1062 & 0 & 0 & 0.0300 \\
\hline C4 & 0 & 0.2842 & 0 & 0.1829 \\
\hline C5 & 0 & 0.6194 & 0 & 0.3985 \\
\hline C6 & 0 & 0.0964 & 0 & 0.0620 \\
\hline C7 & 0 & 0 & 0.0795 & 0.0059 \\
\hline C8 & 0 & 0 & 0.1603 & 0.0118 \\
\hline C9 & 0 & 0 & 0.4658 & 0.0344 \\
\hline C10 & 0 & 0 & 0.2944 & 0.0217 \\
\hline
\end{tabular}

\subsection{Evaluation of Regional Innovation Ability in Beijing-Tianjin-Hebei Region}

\subsubsection{Data collection}

Table2. Statistics of Innovation Indexes in Beijing-TianjinHebei Region (2019)

\begin{tabular}{|c|c|c|c|c|}
\hline \multicolumn{2}{|c|}{ Index } & Beijing & tianjin & hebei \\
\hline \multirow{3}{*}{$\begin{array}{l}\text { Regional } \\
\text { Innovation } \\
\text { Foundation }\end{array}$} & $\begin{array}{l}\text { GDP per } \\
\text { capital (ten } \\
\text { thousand } \\
\text { yuan) }\end{array}$ & 16.4220 & 9.0306 & 4.6348 \\
\hline & $\begin{array}{l}\text { Number of } \\
\text { R\&D } \\
\text { personnel }\end{array}$ & 464178 & 143888 & 62972 \\
\hline & $\begin{array}{l}\text { Number of } \\
\text { universities }\end{array}$ & 116 & 56 & 122 \\
\hline \multirow{3}{*}{$\begin{array}{l}\text { Innovation } \\
\text { investment }\end{array}$} & $\begin{array}{c}\text { Full-time } \\
\text { equivalent of } \\
\text { R\&D } \\
\text { personnel } \\
\text { (person-years) }\end{array}$ & 313986 & 92502 & 20300 \\
\hline & $\begin{array}{c}\text { Internal } \\
\text { expenditure of } \\
\text { R\&D funds } \\
\text { (ten thousand } \\
\text { yuan) }\end{array}$ & 22335870 & 4587000 & 4386000 \\
\hline & $\begin{array}{c}\text { Financial } \\
\text { Technology } \\
\text { Appropriations } \\
\text { (100 million) }\end{array}$ & 10692236 & 700000 & 1200000 \\
\hline \multirow[t]{2}{*}{$\begin{array}{c}\text { Innovation } \\
\text { output }\end{array}$} & $\begin{array}{l}\text { Number of } \\
\text { scientific } \\
\text { papers } \\
\text { published by } \\
\text { institutions of } \\
\text { higher } \\
\text { learning }\end{array}$ & 131118 & 25389 & 33401 \\
\hline & $\begin{array}{l}\text { Number of } \\
\text { patents } \\
\text { granted }\end{array}$ & 131716 & 57799 & 57808 \\
\hline
\end{tabular}




\begin{tabular}{|c|c|c|c|c|}
\hline & $\begin{array}{c}\text { Contract value } \\
\text { of technology } \\
\text { market (100 } \\
\text { million) }\end{array}$ & 5695.3 & 922.63 & 382.46 \\
\cline { 2 - 5 } & $\begin{array}{c}\text { Sales income } \\
\text { of new } \\
\text { products of } \\
\text { industrial } \\
\text { enterprises } \\
\text { above } \\
\text { designated } \\
\text { size (ten } \\
\text { thousand } \\
\text { yuan) }\end{array}$ & 52201988 & 22808.58 & 6662.3 \\
\hline
\end{tabular}

Source: The data are from Beijing Statistical Yearbook 2020; Tianjin Statistical Yearbook 2020; Hebei Statistical Yearbook 2020; China Statistical Yearbook 2020.

\subsubsection{Weighted standardization of indicators}

Benefit index: $\quad v_{i j}=\frac{x_{i j}-\max x_{j}-\min x_{j}}{\max }$

$$
v_{i j}=\frac{x_{i j}-\min x_{j}}{\max x_{j}-\min x_{j}}
$$

$$
\begin{aligned}
& v_{i j}=\frac{\max x_{j}-x_{i j}}{\max x_{j}-\min x_{j}}(2) \\
& \text { Cost index: } \\
& r_{i j}=v_{i j} * w_{j}(\mathrm{i}=1,2, \cdots, m ; j=1,2 \cdots n)
\end{aligned}
$$

\begin{tabular}{|c|c|c|c|c|}
\hline \multicolumn{2}{|c|}{ Index } & Beijing & tianjin & hebei \\
\hline \multirow{3}{*}{$\begin{array}{l}\text { Regional } \\
\text { Innovation } \\
\text { Foundation }\end{array}$} & $\begin{array}{c}\text { GDP per capita } \\
\text { (ten thousand } \\
\text { yuan) }\end{array}$ & 1 & 0.373 & 0 \\
\hline & $\begin{array}{c}\text { Number of } \\
\text { R\&D personnel }\end{array}$ & 1 & 0.202 & 0 \\
\hline & $\begin{array}{l}\text { Number of } \\
\text { universities }\end{array}$ & 0.909 & 0 & 1 \\
\hline \multirow{3}{*}{$\begin{array}{l}\text { Innovation } \\
\text { investment }\end{array}$} & $\begin{array}{c}\text { Full-time } \\
\text { equivalent of } \\
\text { R\&D personnel } \\
\text { (person-years) }\end{array}$ & 1 & 0.246 & 0 \\
\hline & $\begin{array}{c}\text { Internal } \\
\text { expenditure of } \\
\text { R\&D funds (ten } \\
\text { thousand yuan) }\end{array}$ & 1 & 0.011 & 0 \\
\hline & $\begin{array}{c}\text { Financial } \\
\text { Technology } \\
\text { Appropriations } \\
\text { (100 million) }\end{array}$ & 1 & 0 & 0.050 \\
\hline \multirow{4}{*}{$\begin{array}{l}\text { Innovation } \\
\text { output }\end{array}$} & $\begin{array}{c}\text { Number of } \\
\text { scientific papers } \\
\text { published by } \\
\text { institutions of } \\
\text { higher learning }\end{array}$ & 1 & 0 & 0.076 \\
\hline & $\begin{array}{c}\text { Number of } \\
\text { patents granted }\end{array}$ & 1 & 0 & 0 \\
\hline & $\begin{array}{l}\text { Contract value } \\
\text { of technology } \\
\text { market (100 } \\
\text { million) }\end{array}$ & 1 & 0.102 & 0 \\
\hline & $\begin{array}{l}\text { Sales income of } \\
\text { new products of } \\
\text { industrial } \\
\text { enterprises } \\
\text { above } \\
\text { designated size } \\
\text { (ten thousand } \\
\text { yuan) }\end{array}$ & 1 & 0 & 0 \\
\hline
\end{tabular}

Table3. Standardized data on innovation indicators in the Beijing-Tianjin-Hebei region (2019).

\subsubsection{Beijing-Tianjin-Hebei regional innovation ability score}

Combine the statistical data with the weight value of AHP, and adopt the quantitative weighting function method to evaluate the ability of technological innovation. That is: total score $=$ indicator weight $*$ standardized data.

Table4. Beijing-Tianjin-Hebei regional innovation ability score.

\begin{tabular}{|c|c|c|c|}
\hline Area & Beijing & Tianjin & Hebei \\
\hline $\begin{array}{c}\text { Regional } \\
\text { innovation } \\
\text { ability } \\
\text { score }\end{array}$ & 0.997 & 0.135 & 0.034 \\
\hline
\end{tabular}

Evaluation results: It can be concluded from the indicator weights that, in terms of innovation foundation, GDP per capita is a key indicator for evaluating regional innovation capabilities; in terms of innovation input, $\mathrm{R} \& \mathrm{D}$ expenditure input is a key indicator for evaluating regional innovation capabilities; in terms of innovation output, Technology market turnover is a key indicator for evaluating regional innovation capabilities. From the collected index data, it can be seen that Hebei Province is lower than Beijing and Tianjin in terms of per capita GDP, R\&D investment, and technology market turnover.

From the regional innovation ability score, it can be concluded that the comprehensive innovation ability of Hebei Province is weaker than that of Beijing and Tianjin. In particular, there is a large gap between Hebei Province's innovation input and innovation output. Therefore, Hebei Province has strengthened its innovation input and innovation output.

\section{Conclusion and outlook}

R\&D talents are the mainstay of scientific and technological innovation. Judging from the full-time equivalent of $R \& D$ personnel in the entire region, the total R\&D investment in Beijing-Tianjin-Hebei is relatively large, but the R\&D personnel investment in Tianjin and Hebei Province is still far behind Beijing. First, universities, scientific research institutions and high-tech enterprises in Hebei Province should continue to attract external technical talents, and the government can formulate preferential policies on attracting talents, such as solving household registration and providing housing subsidies; Second, they should continue to build a platform for talent exchange and sharing, and encourage regional exchange and cooperation of scientific research talents. Finally, it can provide talent basis for regional coordinated development.

The Hebei government should play the role of toplevel design. First, we must improve the regional collaborative innovation mechanism. Secondly, it is necessary to improve the laws and regulations on the protection of intellectual property rights and improve the management and service level of intellectual property rights. Third, we must build a multi-level technology investment and financing mechanism. Finally, preferential tax and fee policies for high-tech industries 
can be formulated. In short, government departments can provide a good environment for the coordinated and innovative development of the Beijing-Tianjin-Hebei high-tech industry from many aspects.

In terms of innovation investment in higher education institutions, Beijing and Tianjin are in an advantageous position, while Hebei Province is relatively backward. To realize the integrated and coordinated development of Beijing-Tianjin-Hebei, Hebei Province must rise to catch up. First, the government should increase funding for scientific and technological innovation in universities. In addition, through cooperation with enterprises, they can obtain funding from enterprises and expand funding sources. Secondly, we must also attach importance to the construction of discipline groups in institutions of higher learning. Finally, high-quality educational resources must be shared among universities. Colleges and universities will increase the hiring and exchange of teacher resources offline, and improve the online teaching platform online to enable real-time teaching.

\section{References}

1. B.Z.Li, Research on Evaluation of Original Innovation Ability of Large-scale Enterprises in my country Based on Analytic Hierarchy Process, Technological progress and countermeasures, 2010(1): 125-129.

2. Y.H.Xiao, X.W.Zhang and Q.W.Wang, Research on Evaluation of Innovation Ability of my country's High-tech Zones Based on Analytic Hierarchy Process, Economic issues, 2012( 1) : 31-34.

3. G.M.Yang and K.R.Zhang, Evaluation of Agricultural Science and Technology Innovation Ability in Anhui Province Based on Analytic Hierarchy Process, Journal of Chengdu Normal University, 2017( 8) : 119 -123.

4. Y.L.Xia and D.Li, Evaluation of Innovation Ability of Agricultural Science Parks Based on Analytic Hierarchy Process: Taking Anhui as an Example, Journal of Wanxi University, 2017( 5) : 54-60.

5. T.Wang and R.F.Li, Research on Classification and Spatial Layout of Technical Innovation Capability of National High-tech Zones, Productivity research, 2010( 9) : 91-94.

6. Y.X.Zhang, Evaluation of Hefei's Science and Technology Innovation Development: Based on Data Envelopment Analysis, Anhui Science and Technology, 2017( 9) : 11-13.

7. X.Chen, Evaluation and Comparative Study of Regional Enterprises' Independent Innovation Ability Based on TOPSIS Method, Technological progress and countermeasures, 2009(8) : 131-134.

8. H.L.Yu and W.F.Xue, Analysis on the Scientific and Technological Innovation Ability of Hebei Universities, Science and Technology Management Research, 2008(6): 182-185.

9. Z.J.Song, X.P.Xue and N.Liu, Research on the Improvement of Hebei Province's Regional
Innovation Capability under the Integration of Beijing-Tianjin-Hebei, Science and Technology Management Research, 2008, 28(6):215-219.

10. X.P.Pang and Y.Zhao, An Empirical Study on the Fuzzy Comprehensive Evaluation of Hebei's Science and Technology Innovation Ability, Journal of Hebei University of Economics and Business, 2013, 34(6):132-138. 